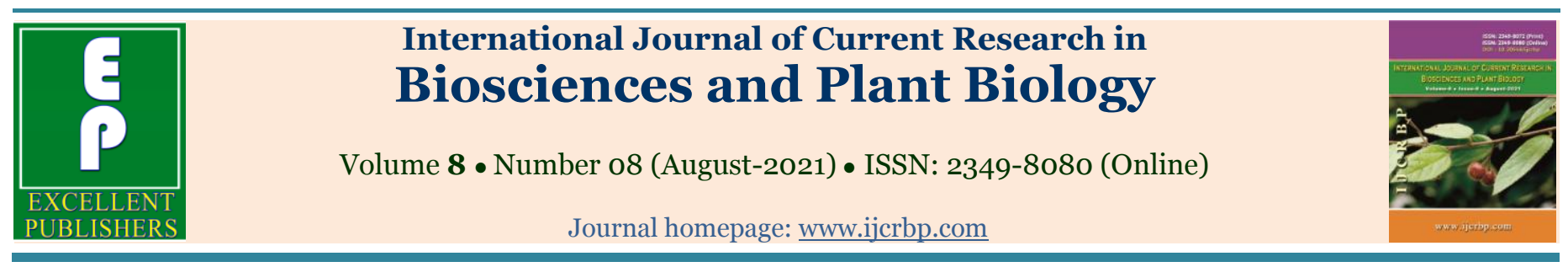

\title{
Diversity of climbers in Vallanadu Black-buck Sanctuary, Tuticorin, Tamil Nadu
}

\author{
A. Saravana Ganthi ${ }^{1} *$, K. Subramonian ${ }^{2}$, K. Natarajan ${ }^{3}$ \\ ${ }^{1}$ Department of Botany, Rani Anna Government College for Women, Tirunelveli, Tamil Nadu - 627 008, India \\ ${ }^{2}$ Department of Botany, The MDT Hindu College, Tirunelveli, Tamil Nadu - 627 010, India \\ ${ }^{3}$ Department of Botany, St. Xavier's College, Palayamkottai, Tamil Nadu-627 002, India \\ *Corresponding author; e-mail: $\underline{\text { saran_gan@ @rediffmail.com }}$
}

\begin{tabular}{|c|c|}
\hline Article Info & Abstract \\
\hline $\begin{array}{l}\text { Keywords: } \\
\text { Climbers } \\
\text { Lianas } \\
\text { Scrub forest } \\
\text { Twiners } \\
\text { Vallanadu Black-buck } \\
\quad \text { sanctuary }\end{array}$ & $\begin{array}{l}\text { In climbers the stems are weak and these plants need various climbing devices in order to support } \\
\text { growth and development. The climbers are predominately angiosperms. The present study chiefly } \\
\text { focuses on diversity of climbers in Vallanadu Black-buck Sanctuary. The present study recorded } 28 \\
\text { herbaceous climbers and } 14 \text { lianas from the scrub forest of Vallanadu Black-buck sanctuary. In } \\
\text { dicotyledons, } 15 \text { families containing } 33 \text { genera and } 40 \text { species were recorded. In monocotyledons, } 2 \\
\text { families containing } 1 \text { genus and } 1 \text { species each were recorded. The present study reported invasive } \\
\text { species such as Ipomoea obscura, Ipomoea pes-tigridis, Clitoria ternatea and Passiflora foetida. The } \\
\text { present study recorded } 24 \text { medicinal climbers. Conservation of climber and lianas is the need of the } \\
\text { hour and climbers provide valuable germplasm as medicinal plants for the benefit of humankind. }\end{array}$ \\
\hline - Received. & 26 May 2021 • Revised: 24 July 2021 • Accepted: 29 July 2021 • Published Online: 6 August 2021 \\
\hline
\end{tabular}

\section{Introduction}

Vallanadu Black-buck Sanctuary is located in Tuticorin District, Tamil Nadu. The forest type of this sanctuary is a tropical scrub and the plants of this region are adapted to the arid condition. This type of biome consists of low-lying, dense thorny underbrush with extensive root system. This area receives less rainfall, continuous long summer, plenty of dry winds, poor drainage and medium to poor soil quality. The plants and animals of the tropical scrub forest have adapted to flourish in this harsh environment. The scrub forests are the source of fodder for domestic and range animals also are the source of wood products, water and wildlife (Miller, 1997). In Vallanadu Black-buck Sanctuary forest very few studies have been conducted to highlight the vegetation structure and composition. This study in Vallanadu Scrub Forest was an attempt to document the diversity of climbers in the study area.

\section{Area of study}

The area of study is a protected area Vallanadu Blackbuck sanctuary (Antelope cervicapra) located in the Tuticorin revenue district of south Tamil Nadu. It is an isolated hillocks and ranges between parallels of latitude $8^{\prime} 40^{\prime}$ and $8^{\prime} 44^{\prime}$ and between meridian of latitudes 77' 54 ' and 77'57' within the tropical region. The region is adjacent to the Vallanadu village of Srivaikundam Taluk with scrub forest. It can be reached at a distance 
of $12 \mathrm{~km}$ east of Palayamkottai and $35 \mathrm{~km}$ west of Tuticorin, along national highway 7A. The forest area spread over 2058.83 hectares and the total area of forest boundary is about $30 \mathrm{~km}$. Topographically, Vallanadu forest is divided into three forest reaches and the formation of hills is grouped under two blocks viz., Block A and Block B. Block A is situated on the northern crest comprising a single compartment. Block B comprises the 4 compartments. The National highway No. 7A from Tirunelveli to Tuticorin is transverse between Block A and Block - B. The Vallanadu hills are raised to an elevation of $210 \mathrm{~m}$ above MSL. The trignometrical point of the highest peak in the study area is $218 \mathrm{~m}$. There are many seasonal streams cutting deep ravine all along the hills.

\section{Materials and methods}

The present research was done by extensive survey and field observation of plant species from the study area from April 2006 to March 2008. Field trips (39) were undertaken during field work. The processed plant specimens are kept in The Rapinat Herbarium, Tiruchirapalli (RHT) and the herbarium of survey of Medicinal plants unit, Central council for research in Siddha (CCRS), Palayamkottai, Tirunelveli. The collected specimens were identified with the standard taxonomic literature such as Flora of Presidency of Madras (Gamble and Fischer, 1956) Flora of Tamil Nadu Carnatic (Matthew, 1983 - 1988). All the specimens were identified correctly and described. The specimens were processed for the preparation of Herbarium by standard methods (Santapau, 1973). The field number of the specimens examined with the code $\mathrm{XCH}$, St. Xavier's College, Herbarium. For collect information about the medical uses standard references (Daniel and Umamaheswari, 2001 and Yoganarasiman, 2000) were referred.

\section{Results}

The present study recorded 28 herbaceous climbers and 14 lianas from all the forests types of Vallanadu Blackbuck sanctuary, covering 17 families. In dicotyledons, there are 15 families containing 33 genera and 40 species. In monocotyledons, there are 2 families containing 1 genus and 1 species each (Table 1). Considering all climbers (C) and lianas (L), 26 species are stem twiners, 3 are spiny climbers, 2 are hooked climbers, 8 species are tendril climbers and 3 species are stragglers.
The present study recorded five climber geophytes, of which Asparagus racemosus, Coccinea indica, Corallocarpus epigaeus, Gloriosa superba are with tuberous roots and Cissampelos pareira is rhizomatous. Some of the selected climbers are depicted in Fig. 1.

\section{Endemics}

Asparagus racemosus is reported as a threatened species in Southern Western Ghats (Sarvalingam et al., 2012; Uma and Parthipan, 2015). Gloriosa superba identified as an endangered species in Western Ghats (Amalraj et al., 1991; Sukumaran and Raj, 2007; Gritto et al., 2012). The medicinal climber Hemidesmus indicus reported as a depleted species in Western Ghats (Amalraj et al., 1991; Matthew, 1981-1988; Sukumaran and Raj, 2007). Ceropegia juncea is a peninsular endemic plant recorded in the present study (Daniel and Umamaheshwari, 2001). According to IUCN conservation status 38 plants were categorized under "Not Evaluated" and 3 species (Rhynchosia minima, Gloriosa superba and Desmodium triflorum) included in "Least Concern" and one species (Abrus fruticulosus) included under "Data Deficient".

\section{Exotics}

The ENVIS database on floral diversity of Tamil Nadu (http://tnenvis.nic.in/) reports a total of 1226 taxa as introduced. This accounts for $22 \%$ of the total flora of Tamil Nadu. About 79\% of the alien flora of Tamil Nadu exists only under cultivation; 200 alien species occur as naturalized weeds and another 56 species are found both in cultivation as well as escapes which are naturalized. The present study reported invasive species such as Ipomoea obscura, Ipomoea pes-tigridis, Clitoria ternatea and Passiflora foetida.

\section{Distribution of climbers at Vallanadu Black-buck sanctuary}

Capparis sepiaria, Abrus fruticulosus and Asparagus racemosus are large shrubs found common mixed with Euphorbia antiquarum and Euphorbia tortilis especially on the northern and eastern foot hill. Cissampelos pareira, Cissus quadrangularis and Abrus precatorius are common in foot hill region as an extensive climber forming a thicket, Cocculus hirsutus and Canavalia virosa are straggling over bushes and small trees. They are common in slopes. Grewia flavescens is common in the north-west foot hill region. 
Table 1. List of climbers in Black-buck sanctuary, Vallanadu, Tamil Nadu.

\begin{tabular}{|c|c|c|c|c|c|c|}
\hline $\begin{array}{l}\text { S. } \\
\text { No. }\end{array}$ & Botanical name & $\begin{array}{l}\text { Common } \\
\text { name }\end{array}$ & Family & $\begin{array}{l}\text { Nature of } \\
\text { climbing organ } \\
\text { (Modification) }\end{array}$ & $\begin{array}{l}\text { Model of } \\
\text { climbing }\end{array}$ & $\begin{array}{l}\text { Flowering } \\
\text { and fruiting }\end{array}$ \\
\hline 1. & $\begin{array}{l}\text { Abrus fruticulosus Wight \& } \\
\text { Arn. }\end{array}$ & - & Fabaceae & $\begin{array}{l}\text { Main stem and } \\
\text { branches }\end{array}$ & Twiner & Nov. - Mar. \\
\hline 2. & $\begin{array}{l}\text { Abrus precatorius } \mathrm{L} . \mathrm{ssp} . \\
\quad \text { precatorius }\end{array}$ & $\begin{array}{l}\text { Indian } \\
\text { Liquorice }\end{array}$ & Fabaceae & $\begin{array}{l}\text { Main stem and } \\
\text { branches }\end{array}$ & Twiner & Jan. - Mar. \\
\hline 3. & Asparagus racemosus Willd. & & Asparagaceae & $\begin{array}{l}\text { Main stem and } \\
\text { branches }\end{array}$ & $\begin{array}{l}\text { Spiny } \\
\text { climber }\end{array}$ & Jan. - Apr. \\
\hline 4. & $\begin{array}{l}\text { Canavalia virosa (Roxb.) } \\
\text { Wight \& Arn. }\end{array}$ & $\begin{array}{l}\text { Wild Sword } \\
\text { Bean }\end{array}$ & Fabaceae & $\begin{array}{l}\text { Main stem and } \\
\text { branches }\end{array}$ & Twiner & Oct. - Feb. \\
\hline 5. & Capparis sepiaria $\mathrm{L}$. & $\begin{array}{l}\text { Wild caper } \\
\text { bush }\end{array}$ & Capparaceae & Hooked thorns & Straggler & Dec. - Apr. \\
\hline 6. & Capparis zeylanica $\mathrm{L}$. & Ceylon caper & Capparaceae & Stipular spines & Straggler & Jan. - Apr. \\
\hline 7. & Cardiospermum halicacabum $\mathrm{L}$. & Balloon -vine & Sapindaceae & Petiole modified & $\begin{array}{l}\text { Tendril } \\
\text { climber }\end{array}$ & Oct. - Mar. \\
\hline 8. & Ceropegia juncea Roxb. & - & Apocynaceae & $\begin{array}{l}\text { Main stem and } \\
\text { branches }\end{array}$ & Twiner & Sep. - Jan. \\
\hline 9. & Cissampelos pareira $\mathrm{L}$. & $\begin{array}{l}\text { Velvet leaf } \\
\text { pareire }\end{array}$ & Menispermaceae & $\begin{array}{l}\text { Main stem and } \\
\text { branches }\end{array}$ & Twiner & Feb. - Apr. \\
\hline 10. & Cissus quadrangularis L. & $\begin{array}{l}\text { Adament } \\
\text { climber }\end{array}$ & Vitaceae & Axillary tips & $\begin{array}{l}\text { Tendril } \\
\text { climber }\end{array}$ & Nav. - Jan. \\
\hline 11. & Cissus vitiginea $\mathrm{L}$. & - & Vitaceae & Axillary tips & $\begin{array}{l}\text { Tendril } \\
\text { climber }\end{array}$ & Aug. - Dec. \\
\hline 12. & Clitoria ternatea $\mathrm{L}$. & Butterfly pea & Fabaceae & $\begin{array}{l}\text { Main stem and } \\
\text { branches }\end{array}$ & Twiner & Jan. - Jun. \\
\hline 13. & Coccinia grandis L. Voigt. & Ivy gourd & Cucurbitaceae & Stipules modified & $\begin{array}{l}\text { Tendril } \\
\text { climber }\end{array}$ & Nov. - Mar. \\
\hline 14. & Cocculus hirsutus (L.) Diels & $\begin{array}{l}\text { Broom } \\
\text { creeper }\end{array}$ & Menispermaceae & $\begin{array}{l}\text { Main stem and } \\
\text { branches }\end{array}$ & Twiner & Jan. - Dec. \\
\hline 15. & $\begin{array}{l}\text { Corallocarpus epigaeus } \\
\text { (Roettl.) Hook. f. }\end{array}$ & - & Cucurbitaceae & Stipules modified & $\begin{array}{l}\text { Tendril } \\
\text { climber }\end{array}$ & Nov. - Mar. \\
\hline 16. & $\begin{array}{l}\text { Ctenolepis garcini }(\mathrm{L} .) \\
\text { C.B.Clarke }\end{array}$ & - & Cucurbitaceae & Stipules modified & $\begin{array}{l}\text { Tendril } \\
\text { climber }\end{array}$ & Nov. - Jan. \\
\hline 17. & $\begin{array}{l}\text { Cyphostemma setosum (Roxb.) } \\
\text { Alston }\end{array}$ & - & Vitaceae & Axillary tips & $\begin{array}{l}\text { Tendril } \\
\text { climber }\end{array}$ & Oct. - Mar. \\
\hline 18. & Desmodium triflorum (L.) DC. & $\begin{array}{l}\text { Three } \\
\text { flowered } \\
\text { trickle foil }\end{array}$ & Fabaceae & $\begin{array}{l}\text { main stem and } \\
\text { branches }\end{array}$ & Twiner & Nov. - Feb. \\
\hline 19. & Gloriosa superba L. & $\begin{array}{l}\text { Malabar } \\
\text { Glory lily }\end{array}$ & Colchicaceae & Leaf & Leaf climber & Oct. - Dec. \\
\hline 20. & Grewia flavescens Juss. & - & Malvaceae & Stem & Straggler & Oct. - Feb. \\
\hline 21. & Grewia umbellifera Bedd. & $\begin{array}{l}\text { Ghat } \\
\text { gooseberry }\end{array}$ & Malvaceae & Stem & Straggler & Jan. - Dec. \\
\hline 22. & $\begin{array}{l}\text { Hemidesmus indicus (L.) R. Br. } \\
\quad \text { ex Schult. var. indicus }\end{array}$ & - & Apocynaceae & $\begin{array}{l}\text { main stem and } \\
\text { branches }\end{array}$ & Twiner & Oct. - Jan. \\
\hline
\end{tabular}


Table 1. Cntd...

\begin{tabular}{|c|c|c|c|c|c|c|}
\hline $\begin{array}{l}\text { S. } \\
\text { No. }\end{array}$ & Botanical name & $\begin{array}{l}\text { Common } \\
\text { name }\end{array}$ & Family & $\begin{array}{l}\text { Nature of } \\
\text { climbing organ } \\
\text { (Modification) }\end{array}$ & $\begin{array}{l}\text { Model of } \\
\text { climbing }\end{array}$ & $\begin{array}{l}\text { Flowering } \\
\text { and fruiting }\end{array}$ \\
\hline 23. & $\begin{array}{l}\text { Hemidesmus indicus var. } \\
\text { pubescens (Wight \& Arn.) } \\
\text { Hook. f. }\end{array}$ & - & Apocynaceae & $\begin{array}{l}\text { Main stem and } \\
\text { branches }\end{array}$ & Twiner & Aug. - Dec. \\
\hline 24. & Hugonia mystax $\mathrm{L}$ & Climbing flax & Linaceae & Peduncle & $\begin{array}{l}\text { Hook } \\
\text { climber }\end{array}$ & Jan. - Dec. \\
\hline 25. & $\begin{array}{l}\text { Ichnocarpus frutescens (L.) } \\
\text { W.T.Aiton. }\end{array}$ & Black creeper & Apocynaceae & $\begin{array}{l}\text { Main stem and } \\
\text { branches }\end{array}$ & Twiner & $\begin{array}{l}\text { Oct. - Jan. } \\
\text { Jun. - } \\
\text { Aug. }\end{array}$ \\
\hline 26. & $\begin{array}{l}\text { Ipomoea marginata (Desr.) } \\
\text { Verdc. }\end{array}$ & - & Convolvulaceae & $\begin{array}{l}\text { Main stem and } \\
\text { branches }\end{array}$ & Twiner & Nov. - Jan. \\
\hline 27. & $\begin{array}{l}\text { Ipomoea obscura (L.) Ker } \\
\text { Gawl. }\end{array}$ & Lesser Glory & Convolvulaceae & $\begin{array}{l}\text { Main stem and } \\
\text { branches }\end{array}$ & Twiner & Jan. - Dec. \\
\hline 28. & Ipomoea pes-tigridis L. & $\begin{array}{l}\text { Tiger's foot } \\
\text { creeper }\end{array}$ & Convolvulaceae & $\begin{array}{l}\text { Main stem and } \\
\text { branches }\end{array}$ & Twiner & Jan. - Dec. \\
\hline 29. & $\begin{array}{l}\text { Jasminum angustifolium (L.) } \\
\text { Willd. }\end{array}$ & Wild Jasmine & Oleaceae & $\begin{array}{l}\text { Main stem and } \\
\text { branches }\end{array}$ & Twiner & Jun. - Aug. \\
\hline 30. & $\begin{array}{l}\text { Macrotyloma uniflorum (Lam.) } \\
\text { Verdc. }\end{array}$ & Horse gram & Fabaceae & $\begin{array}{l}\text { Main stem and } \\
\text { branches }\end{array}$ & Twiner & Feb. - May \\
\hline 31. & $\begin{array}{l}\text { Merremia tridentata (L.) Hall. } \\
\text { fil. }\end{array}$ & - & Convolvulaceae & $\begin{array}{l}\text { Main stem and } \\
\text { branches }\end{array}$ & Twiner & Jan. - Mar. \\
\hline 32. & $\begin{array}{l}\text { Mukia maderaspatana (L.) } \\
\text { M.Roem. }\end{array}$ & $\begin{array}{l}\text { Madras pea } \\
\text { pumpkin }\end{array}$ & Cucurbitaceae & Stipule & $\begin{array}{l}\text { Tendril } \\
\text { climber }\end{array}$ & Oct. - Feb. \\
\hline 33. & Passiflora foetida $\mathrm{L}$. & Passion flower & Passifloraceae & $\begin{array}{l}\text { Main stem and } \\
\text { branches }\end{array}$ & Twiner & Oct. - Mar. \\
\hline 34. & $\begin{array}{l}\text { Pentatropis capensis (L. f.) } \\
\text { Bullock }\end{array}$ & Salt killer vine & Apocynaceae & $\begin{array}{l}\text { Main stem and } \\
\text { branches }\end{array}$ & Twiner & $\begin{array}{l}\text { Jan. - Dec., } \\
\text { Jun. - Aug. }\end{array}$ \\
\hline 35. & $\begin{array}{l}\text { Pergularia daemia (Forsk.) } \\
\text { Chiov. }\end{array}$ & Trellis vine & Apocynaceae & $\begin{array}{l}\text { Main stem and } \\
\text { branches }\end{array}$ & Twiner & Aug. - Feb. \\
\hline 36. & $\begin{array}{l}\text { Reissantia indica (Willd.) } \\
\text { N.Hallé. }\end{array}$ & - & Celastraceae & $\begin{array}{l}\text { Main stem and } \\
\text { branches }\end{array}$ & Twiner & Feb. - May \\
\hline 37. & $\begin{array}{l}\text { Rhynchosia minima (L.) DC. } \\
\text { LC }\end{array}$ & - & Fabaceae & $\begin{array}{l}\text { Main stem and } \\
\text { branches }\end{array}$ & Twiner & Dec. - Feb. \\
\hline 38. & $\begin{array}{l}\text { Rivea hypocrateriformis (Desr.) } \\
\text { Choisy }\end{array}$ & $\begin{array}{l}\text { Midnapore } \\
\text { creeper }\end{array}$ & Convolvulaceae & $\begin{array}{l}\text { Main stem and } \\
\text { branches }\end{array}$ & Twiner & Nov. - Feb. \\
\hline 39. & $\begin{array}{l}\text { Sarcostemma acidum (Roxb.) } \\
\text { Voigt. }\end{array}$ & Moon creeper & Apocynaceae & $\begin{array}{l}\text { Main stem and } \\
\text { branches }\end{array}$ & Twiner & Jan. - Apr. \\
\hline 40. & Solanum trilobatum $\mathrm{L}$. & $\begin{array}{l}\text { Climbing } \\
\text { brinjal }\end{array}$ & Solanaceae & Stem & $\begin{array}{l}\text { Spiny } \\
\text { climber }\end{array}$ & Nov. - Mar. \\
\hline 41. & $\begin{array}{l}\text { Tinospora cordifolia (Willd.) } \\
\text { Mers. }\end{array}$ & $\begin{array}{l}\text { Heart leaf } \\
\text { moon seed }\end{array}$ & Menispermaceae & $\begin{array}{l}\text { Main stem and } \\
\text { branches }\end{array}$ & Twiner & May - Aug. \\
\hline 42. & $\begin{array}{l}\text { Ziziphus nummularia (Burm.f.) } \\
\text { Wight \& Arn. }\end{array}$ & Wild jujube & Rhamnaceae & Armed stem & Straggler & Apr. - Aug. \\
\hline
\end{tabular}




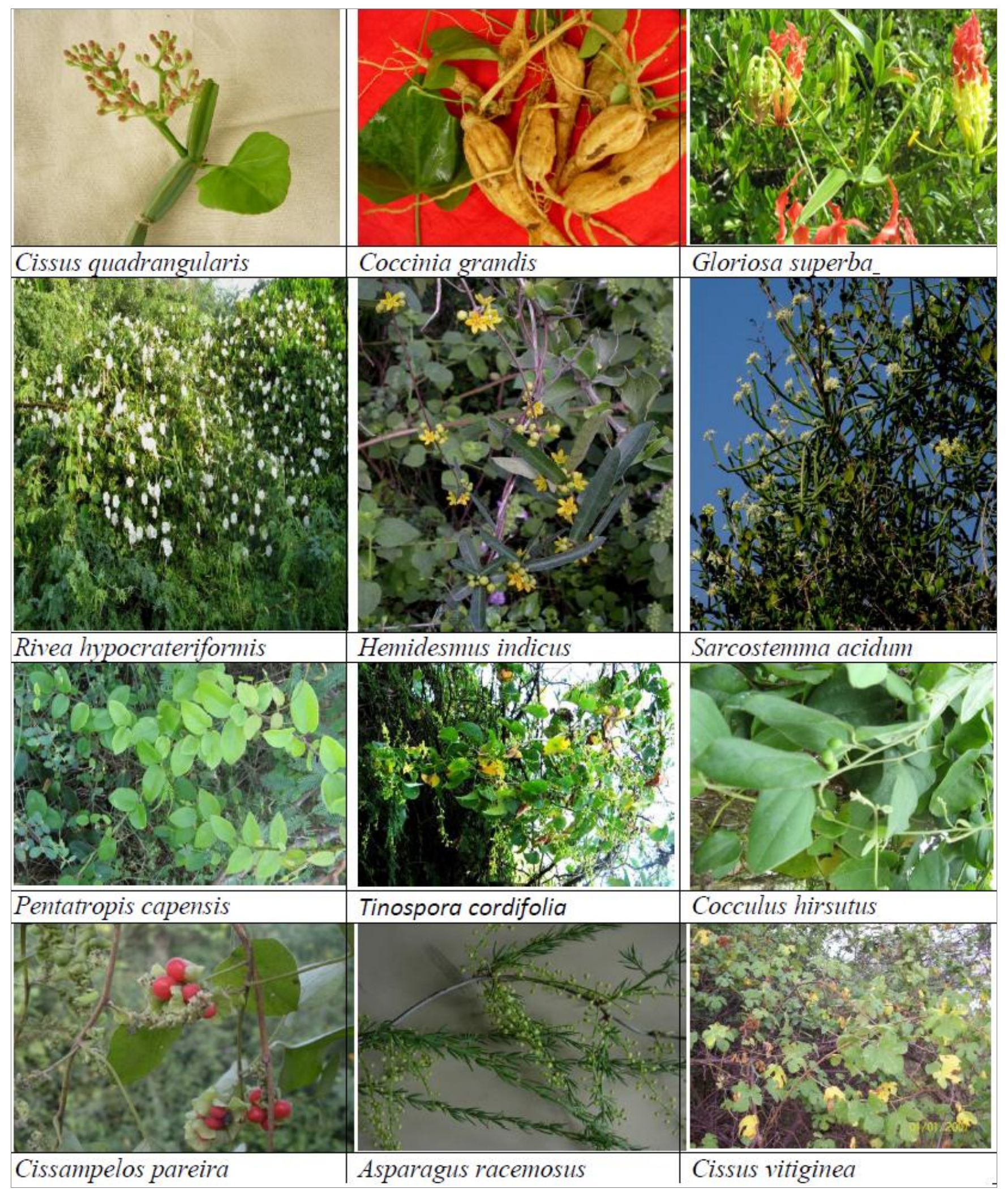

Fig. 1: Selected climbers in the study site. 
Reissantia indica, Hugonia mystax, Coccinia grandis, Mukia maderaspatana, Hemidesmus indicus, Pergularia daemia, Ipomoea obscura and Rivea hypocrateriformis are common throughout the forest. Ziziphus nummularia, Gloriosa superba, Cardiospermum halicacabum and Passiflora foetida are found along with road sides and waysides. Cissus vitiginea is rare and found at the top and upper slope of the hill. Clitoria ternatea, Rhynchosia minima, Ichnocarpus frutescens and Solanum trilobatum are less common in the forest. Ctenolepis garcini are forming a mat on bushes and thickets. Cyphostemma setosum and Desmodium triflorum are a found on thickets and bushes in moist shady places. Sarcostemma acidum is hanging from Euphorbia and Dalbergia in foot hills.

\section{Economical importance}

Canavalia virosa fruits are used as vegetable. Ipomoea obscura and Ipomoea marginata young leaves used as spinach. Reissantia indica is considered to be good fodder for goats and local villagers believed that it increases their fat content. So it is widely disturbed by local people and grazing goats. It is also a favourite fodder for native Black-bucks. The present study recorded 24 medicinal climbers (Table 2).

\section{Discussion}

Similar to present study, previous reports on climber diversity at Southern Western Ghats of Coimbatore (Sarvalingam and Rajendran, 2015), in Rajshahi region, Bangladesh (Rony Rani et al., 2019), North-Eastern Uttar Pradesh, India (Dvivedi et al., 2016), in Koch Bihar District of West Bengal, India (Bandopadhya and Mukherjee, 2010), in Northern Telangana (Suthari et al., 2014), in Point Calimere Wildlife and Bird Sanctuary Padma Sorna Subramanian et al. (2020) and in Monghyr district (Bihar). (Singh, 1990) also recorded taxonomic and ecological diversity of climbing plants. Muthumperumal and Parthasarathy (2010), Reddy and Parthasarathy (2003), Mascaro et al. (2004), Appanah et al. (1999), Perez-Salicrup et al. (2001), Parthasarathy et al. (2004), Nabe-NIelsen et al. (2001) reported on the lianas diversity in various forests.

The fragmented area of forest is dominated by lianas. The large lianas suppress the tree growth and reduce tree biomass (Laurance, 2001). The increase in lianas changes the structural and functional composition of forests. The lianas over $10 \mathrm{~cm}$ in diameter, measured at a height of 1.5 to 2.5 metres. Lianas support greater biomass and productivity than trees of equal diameter (Schnitzer and Bongers, 2002; Gerwing and Lopes Farias, 2000). The commonest liana species in the studied forest include Jasminum angustifolium and Coccinia grandis. The most infested host species are Acacia and Dalbergia.

Rhynchosia minima, Mukia maderaspatana, Macrotyloma uniflorum, Ipomoea obscura and Desmodium triflorum are common climbers during rainy seasons. The flowering phonology of climbers in the study area depends on the duration and intensity of light as well as temperature. The climatic conditions such as temperature (Ashton et al., 1988), rainfall (Dutta and Devi, 2015; Mouplea et al., 2014; Opler et al., 1976) and water stress (Borchert, 1983) influence the flowering. Reissantia indica, Cissampelos pareira, Capparis zeylanica and Asparagus racemosus starts flowering and fruiting during sunniest months of the year, so the seed maturation occur during the south west monsoon.

Hemidesmus indicus, Jasminum angustifolium, Ziziphus nummularia and Tinospora cordifolia starts flowers during long summer with occasional rains. This heavy rain stimulates flowering and followed by fruiting. The maturation of fruit and dispersal of seeds occur with the onset of North West monsoon. The species such as Ceropegia juncea, Cissus quadrangularis, Coccinia grandis, Ctenolepis garcini, Desmodium triflorum, Gloriosa superba and Rivea hypocrateriformis starts flowering during the middle of the rainy season and shed the seeds during at the end of the rainy season. In Grewia flavescens and Grewia umbellifera fruiting peak occur during post monsoon season. Pentatropis capensis and Ichnocarpus frutescens exhibits two peaks of flowering in a year. Environmental cues exactly control the seasonal flowering (Frankie et al., 1974; Reich and Borchert, 1984; Borchert, 1994; Lobo et al., 2003).

\section{Conclusions}

The diversity and role of climbers depends upon the climate and environmental factors. Climbing plants account for significant portion in the tropical scrub forests. The lianas are nesting site for many birds in the study area and it provide important role in forest regeneration as they keep many pollinators for flowering plants. 


\section{Conflict of interest statement}

Authors declare that they have no conflict of interest.

\section{References}

Amalraj, V.A., Velayudhan, K.C., Abraham, Z., 1991. Threatened medicinal plants in Western Ghats. In: Karunakaran, C.K. (Ed), Proc. of the Symposium on Rare, Endangered and Endemic Plants of Western Ghats, pp.215-220.

Appanah, S., Gentry, A.H., LaFrankie, J.V., 1999. Liana diversity and species richness of Malaysian Rain Forests. J. Trop. For. Sci., 6(2): 116 -123.

Ashton, P. S., Givnish, J.P., Appanah, S., 1988. Staggered flowering in the Dipterocarpaceae: New insights into floral induction and evolution of mast fruiting in the seasonal tropics. Amer. Naturalist, 132: 44-66.

Bandopadhya, S., Mukherjee, S. K., 2010. Diversity of climbing plants in Koch Bihar district of West Bengal, India. Pleione, 4(1): 82-89.

Borchert, R., 1983. Phenology and control of flowering in tropical trees. Biotropica, 15: 81-89.

Borchert, R., 1994. Soil and stem water storage determine phenology and distribution of tropical dry forest trees. Ecology, 75: 1437-1449.

Daniel, P., Umamaheswari, P., 2001. The Flora of the Gulf of Mannar, Southern India. Botanical Survey of India, Coimbatore.

Dutta, G., Devi, A., 2015. Phenology and population structure of six tree species in tropical forest of Assam, Northeast India. Trop. Ecol., 56: 343-399.

Dvivedi, A., Srivastava, S., Shukla, R. P., 2016. Climber diversity across vegetational landscape of North-Eastern Uttar Pradesh, India. Not. Sci. Biol., 8(4): 489-497.

Frankie, G., Baker, W.H.G., Opler, P.A., 1974. Comparative phenological studies of trees in tropical wet and dry forests in the lowlands of Costa Rica. J. Ecol., 62: 881- 913.

Gamble, J.S., Fischer, C.F.S., 1956. Flora of the Presidency of Madras, London.

Gerwing, J.J., Lopes Farias, D., 2000. Integrating liana abundance and forest stature into an estimate of total aboveground biomass for an eastern Amazonian forest. J. Trop. Ecol., 16: 327-335.

Gritto, M.J., Aslam, A., Nandagopalan, V., 2012. Ethnomedicinal survey of threatened plants in Pachamalai hills, Tiruchirapalli district, Tamilnadu, India. Int. J. Res. Ayur. Pharm., 3(6): 844-846.
Laurance, W.F., 2001. Rain forest fragmentation and the structure of Amazonian liana communities. Ecology, 82: 105-116.

Lobo, J.A., Quesada, M., Stoner, K.E., Fuchs, E.J., Herrerías-Diego, Y., Rojas, J., Saborío, G., 2003. Factors affecting phenological patterns of bombacaceous trees in seasonal forests in Costa Rica and Mexico. Amer. J. Bot., 90: 1054-1063.

Mascaro, J.S., Schnitzer, S.A., Carson, W.P., 2004. Liana diversity, abundance and mortality in a tropical wet forest in Cost Rica. Forest Ecol. Manage., 190: 3-14.

Matthew, K.M., 1981-1988. Flora of Tamil Nadu Carnatic. The Raphinat Herbarium, Tiruchirapalli, India.

Miller, D., 1997. Rangelands and Range Management. Newsletter, ICIMOD, 27.

Moupela, C., Doucet, J.L., Kasso, D., Yves, B., Adeline, F., Cedric, V., 2014. Reproductive ecology of a volnable non-timber forest product. Trop. Ecol., 55: 327-338.

Muthumperumal, C., Parthasarathy, N., 2010. A largescale inventory of liana diversity in tropical forests of south Eastern Ghats, India. Syst. Biodivers., 8(2): 289-300.

Nabe-Nielsen, J., 2001. Diversity and distribution of lianas in a neotropical rain forest, Yasuna National Park, Ecuador. J. Trop. Ecol., 17: 1-19.

Opler, A., Frankie, G., Baker, H., 1976. Rainfall as a factor in the release, timing, and synchronization of anthesis of tropical trees and shrubs. J. Biogeogr., 3: 231-236.

Padma Sorna Subramanian, M., Saravana Ganthi, A., Subramonian, K., 2020. Diversity of Angiosperm climber species in Point Calimere Wildlife and Bird Sanctuary, Tamil Nadu. Int. J. Adv. Res., 8(11): 1146-1155.

Parthasarathy, N., Muthuramkumar, S., Sridhar Reddy, M., 2004. Patterns of liana diversity in tropical evergreen forests of peninsular India. Forest Ecol. Manage., 190: 15-31.

Perez-Salicrup, D.R., Sork, V.L., Putz, F.E., 2001. Lianas and trees in a liana forest of Amazonian Bolivia. Biotropica, 33: 34-47.

Reddy, M.S., Parthasarathy, N., 2003. Liana diversity and distribution in four tropical dry evergreen forests on the Coromandel coast of south India. Biodivers. Conserv., 12: 1609-1627.

Reich, P.B., Borchert, R., 1984. Water stress and tree phenology in a tropical dry forest in the lowlands of Costa Rica. J. Ecol., 72: $61-74$. 
Rony Rani, A.K.M,, Rafiul Islam, Mahbubur Rahman, A.H.M., 2002. Diversity of Angiosperm climber species in Rajshahi Region, Bangladesh Int. J. Adv. Res., 7(11): 522-536.

Santapau, H., 1973. A Dictionary of the flowering plants in India. Council of Scientific \& Industrial Research, New Delhi.

Sarvalingam, A., Rajendran, A., 2015. A. Diversity of climber in the Southern Western Ghats of Coimbatore district Tamil Nadu, India National Conference on Conservation of Aquatic and Terrestrial Biodiversity (NCAT 2015) St. John's College, Palayamkottai -627 002, Tamilnadu, India, Jan. 22 - 25: p. $45-47$.

Sarvalingam, A., Rajendran, A., Sivalingam, R., 2012. Documentary of woody flora and its usage in Maruthamalai Hills of the Southern Western Ghats of Coimbatore district, India. Res. Plant Biol., 2(1): 7-14.

Schnitzer, S.A., Bongers, F., 2002. The ecology of lianas and their role in forests. Trends Ecol. Evol., 17: 223-230.

Singh, K.L.B., 1990. Twiners and Climbers of Monghyr district (Bihar). Higher Plants of Indian Subcotinents, pp.183-200.

Sukumaran, S., Raj, A.D.S., 2007. Rare endemic threatened (RET) trees and lianas in the sacred groves of Kanyakumari District. Indian For., 133: 1254-1266.

Suthari, S., Sreeramulu, N., Omkar, K., Raju, V. S., 2014. The Climbing plants of Northern Telangana in India and their ethnomedicinal and economic uses. Indian J. Plant Sci., 3(1): 86-100.

Uma, R., Parthipan, B., 2015. Survey on medicobotanical climbers in Pazhayaruriver bank of Kanyakumari District, Tamilnadu. J. Med. Plants Stud., 3(1): 33-36.

Yoganarasimhan, S. N., 2000. Medicinal plants of Tamil Nadu. Interline Publishing Private Ltd., Bangalore India.

\section{How to cite this article:}

Saravana Ganthi, A., Subramonian, K., Natarajan, K., 2021. Diversity of climbers in Vallanadu Black-buck Sanctuary, Tuticorin, Tamil Nadu. Int. J. Curr. Res. Biosci. Plant Biol., 8(8): 31-38.

doi: https://doi.org/10.20546/ijcrbp.2021.808.004 